\title{
Building the Harmonious Relationship between Librarians and Readers in University Libraries
}

\author{
-A perspective based on the theory of two-way communication
}

\author{
Xihong Li \\ Library. Shandong Technology and Business University \\ Yantai, China \\ E-mail:402650374@qq.com
}

\begin{abstract}
Librarians and readers are the two main bodies of the library, the construction of harmonious relationship between them is the basis of library working smoothly, trying to explain how to effectively build a harmonious relationship between them from the perspective of two-way communication theory.
\end{abstract}

Keywords: University library; Harmonious relationship; Two-way communication; understand

\section{THE PRESENT SITUATION OF RELATIONSHIP BETWEEN LIBRARIANS AND READERS IN UNIVERSITY LIBRARIES}

In the current era of new media, the needs of university readers are diverse and individualized, which is no longer limited to the demand for various traditional paper resources, but a huge demand for digital resources. Thus readers also put forward higher requirements for the library service. But at present, there are still many problems in the daily service of university libraries, especially the disharmony between librarians and readers, which is still a bottleneck restricting the further development of university libraries' service.

The contradiction between librarians and readers mainly reflects in two aspects: the first one is the contradiction of knowledge. There are two main categories of readers in the university library. One group is teachers and scientific researchers. They have a high degree of education, or a master's degree, or a doctor, and need more professional resources. The other group is the students, which include the undergraduates, the masters and the doctors, and they have the good knowledge foundation and a very great desire for knowledge, and their demand is comprehensive. In short, both the students' readers and teachers' readers have a higher level of culture. But librarians do not know or lack the basic knowledge of the library, related professional knowledge and some other related knowledge, and they can not provide readers with personalized and deep service. The second is the contradiction in the status. In the specific service process, the librarians and the readers are in unequal positions because of the different degree of knowing the library resources. The readers believe that the librarians are in a strong position, and the readers are in a relatively weak one.

The main reason is that the librarians can't communicate well with the readers. Therefore, it is the primary task for university libraries to reduce the contradiction between librarians and readers and to improve the service quality through effective communication. The two-way communication theory put is forward by American scholar C Tripp and S. Cutlip in the effective public relations may provide new and useful inspiration.

\section{A SUMMARY OF THE THEORY OF TWO-WAY COMMUNICATION}

The definition of communication in management is that communication is the process of one transmitting the information to the other and expecting the other to make the desired effect. [2] Two-way communication means that the information emanatory and the recipient are constantly changing their position in communication. After the information is sent, it will get feedback, such as conversation and negotiation [2]. The first theory of "two-way communication" in public relations is Cartier and sent. In 1952, they published an authoritative public relations monograph "effective public relations" and discussed the "two-way symmetry" model of public relations. In contemporary public relations, two-way communication theory is generally recognized as the core feature of public relations communication. The core content of [3] two-way communication theory is the basic premise that mutual understanding is used as a mutual cooperation between service providers and service objects, which is composed of the following four basic viewpoints. First, to understand the service object. Man is an emotional animal that needs to be understood. Service providers in the service process, only the correct understanding of the service objects, service providers can talk about their own quality service to fully meet the actual needs of the other. Second, to strengthen mutual understanding. In the communication between people, we must establish this understanding on the basis of mutual understanding in order to achieve the true understanding of the object of communication. Third, to establish communication channels. In order to truly make mutual understanding between the two parties in interpersonal communication, we must rely on the establishment of a communication channel that is mutually acceptable and relatively stable and helps to understand each other in the communication. This communication channel can be regarded as a shortcut to realize mutual understanding 
between the two parties. Fourth, to attach importance to communication skills. Through the use of skillful communication skills, service providers eliminate obstacles in communication and communicate in all directions with the service objects, so as to understand the real needs of the service objects.

\section{THE CONSTRUCTION OF HARMONIOUS RELATIONSHIP BETWEEN UNIVERSITY LIBRARIANS AND READERS BASED ON THE THEORY OF TWO WAY COMMUNICATION}

Librarians and readers are the two main bodies of library service. In the relationship between them, librarians represent libraries, serve as providers and readers are service objects. In the process of providing service from librarians to readers, mutual respect and trust are the prerequisite for equal communication. Good quality is the basis for effective communication. According to the theory of two-way communication, libraries should provide the best services to readers from the following aspects.

\section{A. Librarians Should Understand Readers}

Decru pointed out: "libraries exist for those who are served, that is users, rather than for employees working in libraries." [4] Readers are the basis for libraries to survive, so libraries must put readers in the most position. This requires librarians to understand readers, first of all, to care for readers. Librarians should be careful to communicate with readers, understand their various ideas, understand the importance of the reader's work, grasp the reader's dynamics, and let the readers feel to be concerned and understood. Secondly, Librarians should respect readers. Librarians should be polite and generous when they provide service to readers. Again, Librarians should help readers. Because of the difference of division of labor, readers are in a disadvantaged position on resources and are unfamiliar with the distribution of library resources, and need the help of librarians. The proper help of librarians is the true understanding of readers. Finally, librarians must trust readers. Trust is a link, which can close the distance and reduce obstacles between readers and librarians, , so that librarians can understand the readers well.

\section{B. Strengthening Mutual Understanding between \\ Librarians and Readers -- Transpositional Thinking}

To realize the true understanding of service objects, we must build understanding on the basis of mutual understanding.Mutual understanding enables people with different positions to understand each other so as to reduce misunderstandings. To promote mutual understanding between librarians and readers, "transpositional thinking" should be the first choice. Librarians should stand in the position of readers, to experience the situation, mood and psychology of readers, and provide appropriate service. As readers, they should stand in the position of librarians, experience the hard work and approve the work of them. Readers should also actively participate in the construction of the library, and put forward suggestions for the development of the library. Through "transpositional thinking", we can enhance mutual understanding, mutual respect and mutual trust between librarians and readers.

\section{Establishing Communication Channels}

Communication channels are the prerequisite for truly communication. Libraries should actively adopt various communication channels to enhance effective communication between librarians and readers.

\section{1) Using network tools}

The rapidly changing means of communication provide conditions for the communication channels' broadening of libraries in the information age. Readers' message board, online forum, QQ and micro-blog, librarians' email and many other network tools have greatly widened the channel of communication between the librarians and readers without any limitations, and readers can receive the feedback from the library in time[5].

2) Opening Symposium

The library actively strengthens the contact and communication with the departments, so that the library can directly introduce all resources and service to readers and accurately know about the dynamic needs of readers timely.

\section{3) Setting up a student community}

University Libraries in western countries use college students to participate in the work of the library. They have given a good and professional name to the college students who work in the library, "the library assistant of student". [6] These assistants, as students, can communicate with readers and understand their real ideas and needs easily. This is the most direct and effective channel.

\section{Attaching Importance to Communication Skills}

The application of communication skills can shorten the distance between librarians and readers, and reduce unnecessary conflicts

1) Attaching great importance to language communication skills

Proper use of language is the main tool for librarians and readers to exchange ideas. so librarians should be good at using positive and popular language in order to help readers to understand quickly. (1) Positive language. When librarians communicate with readers in language communication, they should not only pay attention to the tone and speed of the language, but also use the positive language such as " let me help you ", "It' my pleasure" and so on. Because in the reader's view, this kind language is more realistic than "this question, it is the responsibility of other departments ", and it is easily accepted by readers. (2) Popular language. Because different readers are different in educational level, the understanding and cognition of library resource and layout are different. It is necessary for librarians to introduce resources and services in both scientific and popular language. It is easier for readers to understand.

\section{2) Attaching great importance to non-verbal} communication skills

Nonverbal communication skills refer to some nonverbal behaviors, also known as body language. Appropriate body language plays an active role in 
promoting the relationship between librarians and readers. Librarians should pay special attention to their own behaviors. Librarians must be neat in clothing, use language civilization, face up to readers, and communicate with readers as far as possible with a smile, so as to let readers to feel the care .[7]

\section{CONCLUSION}

The good and harmonious relationship between librarians and readers is the basis of the development of libraries. As a university library, we should pay more attention to the construction and maintenance of the harmonious relationship between librarians and various readers so as to make it develop healthfully.

\section{REFERENCES}

[1] $\mathrm{Xu}$ Jinmei. New thoughts on the construction of Harmonious Libraries in Colleges and universities [J]. Henan Library Journal, 2008 (5): 30-32.

[2] Zhou Zhigang, Chen Juan. Brief analysis of the choice and use of two-way communication mode in enterprises [J]. Journal of Liaoning Academy of Governance, 2011 (6): 76-77.

[3] Huang Dongsheng. On the status of public research in the basic theoretical research of public relations [J]. China Higher Education Research, 2006 (7):83-84.

[4] Yan Li Guang, Tian Min. Correctly understanding "reader first" and "librarian first" [J]. Science and Technology Information, 2007 (33): 264.

[5] Zhou Ming. Effective communication between university librarians and readers. [J]. Library Tribune, 2008 (2): 111-112.

[6] Ling Zheng Qiang. Discussion on the Library Management of the Newly Promoted Professional Colleges. [J]. Library Tribune, 2004 (2): 48-51.

[7] Ryde beauty. Communication skills and dispute resolution of outpatient nurses [J]. Jilin Medical Journal, 2012 (3): 644. 